\title{
Total Quality Management (TQM) Implementation in the Manufacturing Sector in Saudi Arabia: A Systematic Review
}

\author{
Khalid Alofi ${ }^{1} \&$ Dr Ahmed Younes ${ }^{2}$ \\ ${ }^{1}$ Teesside university, middlesbrough, UK \\ ${ }^{2}$ MIA Education, Leeds, UK \\ Correspondence: Khalid Alofi, Teesside university, middlesbrough, UK. E-mail: k.alofi@tees.ac.uk
}

Received: March 7, 2019

Accepted: March 22, 2019

Online Published: March 25, 2019

doi:10.5430/bmr.v8n1p41

URL: https://doi.org/10.5430/bmr.v8n1p41

\begin{abstract}
Objective: Despite the widespread adoption of Total Quality Management (TQM) and its theoretical applicability within the institutional framework, in the Middle East, particularly in the Kingdom of Saudi Arabia (KSA), the rhetoric in TQM has weakened the practical application and foundation of TQM as a quality management framework. There is also a scarcity of empirical evidence to support the various theoretical meanings.

Methods: A systematic literature review was conducted to identify, critically evaluate, and understand the findings of current high-quality TQM implementation literature within the manufacturing sector in Saudi Arabia.

Results: The paper highlights that the International Organisation for Standardisation (ISO) 9000 is the most implemented model within the manufacturing sector. However, this sector is still facing numerous challenges in the adoption of TQM such as; the disagreement as per the importance of TQM, the difference in the professional and technical know-how, weaknesses in the training and development systems, and the limitations that plague the institutional frameworks. Furthermore, there is a lack of financial resources to invest in the TQM processes, as well as the negative implications of the development model.

Conclusions: This study provides a systematic review of TQM implementation in the manufacturing sector in Saudi Arabia. The study reveals that ISO 9000 has been the adoptable model in this sector. This systematic review contributes to the understanding of what has been done recently in the field of TQM model implementation, its development and validation in the manufacturing sector in Saudi Arabia. Also, it uncovers eminent study gaps for future research.
\end{abstract}

Keywords: a systematic review, total quality management (TQM) implementation, the manufacturing sector, Saudi Arabia

\section{Introduction}

Ross and Perry (1999, p. 1) state that Total Quality Management (TQM) is the "integration of all functions and processes within an organisation to achieve continuous improvement of the quality of goods and services. The goal is customer satisfaction". TQM is a multifaceted system, which can be viewed as a philosophy, model, strategy or a technique for use in quality management.

Kaynack and Rogers (2013) define TQM as a philosophy that facilitates quality management, by stimulating radical change in the work processes and management approaches. As a philosophy, Baidoun (2004) argues that TQM advocates for integration in business processes and resources, to achieve optimal efficiency and effectiveness, both in revenue generation (productivity) and costs. As a philosophy, TQM fundamentally guides behaviour and choices of all stakeholders within the institution (Kanji, 2012).

To. achieve these quality-oriented goals without losing sight of the economies of scale and scope, Awan, et al. (2009) reiterates the position by Ross and Perry (1999) that frameworks, techniques, strategies and management models play an essential role in guiding institutions to enable them to act suitably. These frameworks are what resulted in the field of quality management, which later evolved to TQM.

However, there is a concern on quality management originated from the highly revered traditional processes involving product testing and inspection. This traditionalist ideology was expended into quality control, and later to quality assurance (Oakland, 2012). Currently, three processes have been incorporated into TQM, including, 
measurement, control and improvement of quality within an institution (Roberts, 2010). Furthermore, the principle of decentralisation implies that most organisations adopt TQM by customising it to each function and level within an organisation (Youseff, 2006). One might argue that this granular approach has led to increased effectiveness and efficiency of the process in quality management (Chiarini, 2012), thereby reinforcing the totality of quality management as implied in the word 'total'.

TQM is a sub-discipline of management sciences which is comprised of a diversity of other competing quality tools (such as quality circles, Kaizen, Six Sigma, Total Productive Maintenance and Quality Function Deployment) and frameworks (including the ISO 9000). These models offer alternative routes to quality management and can thus be considered as being complementary or supplementary strategies for quality management (Waleed, 2012). The existence of these models can be theorised to influence the adoption of TQM. This is because most of the decisions on which model or tool to adopt in quality management processes are dependent on whether there exists a culture of quality management, and whether TQM is perceived as being preferable to the other alternatives. Awan et al. (2009) argue that most institutions adopt quality management frameworks or tools on a trial and error basis, which in turn affects the commitment to achieving success through the process. As a result, despite the recognition of the imperatives of these models within the strategic and operational norms within the firms, there is a lack of appreciation of which models to adopt based on the characteristics of the firm, how to implement the model for optimal success and how to measure its impact and success.

This paper systematically reviews some relevant literature that examines the implementation of TQM and its validation within the manufacturing sector in Saudi Arabia. Also, it evaluates the challenges, obstacles and barriers that the sector might face during the implementation of TQM.

The manufacturing industry was the first sector to standardise TQM while promoting it across the globe. However, the standardisation of TQM in other sectors, such as the service sector is challenging, due to the nature of the value creation process. Whereas the manufacturing industry value chains can be easily mapped and predicted, Irfan and Kee (2013); Larn et al. (2011) and Ooi et al. (2011) indicate that the personalised nature of services complicates the quality management outcomes.

Regardless of the type of sector in which a firm operates, Saravanan and Rao (2006) argue that practical knowledge of TQM, coupled with a clear appreciation of the organisational goals, value propositions, resources (human and capital) are key to achieving the TQM goals.

\section{Method}

Over recent years, there have been numerous investigations and academic studies into TQM implementation and validation in the manufacturing sector in Saudi Arabia. A systematic review was undertaken in this study to investigate the implications of TQM implementation in Saudi Arabia. A keyword search in journal articles, thesis and databases which included empirical and theoretical studies were made on TQM implementation literature published between (1995 - 2018). An additional search was also conducted to cover national and international studies on TQM implementation.

This study only represented empirical and theoretical publications, written in Arabic and English, and the research was focused on TQM implementation and its validation adopted by the manufacturing sector in Saudi Arabia. However, limited studies were found, e.g. just over fifty publications from five to three-star papers and thesis were used in this investigation (see a sample of this paper in table 1).

\section{Findings}

The existing literature on TQM models leads to different conclusions on how such models are or should be developed and validated. Al-Otaibi (2015) and Al-Shafei, et al. (2015) pointed the disparity in conclusions to the two rationales. Firstly, quality management is a complex construct that is achieved at the convergence of the capabilities of the management teams and human resources within an organisation (objective quality). Secondly, the expectations of the customers (subjective quality). The following part of the findings show a summary of systematically reviewed papers and thesis published in TQM implementation and its validation nationally and internationally, which includes the manufacturing sector in Saudi Arabia (See Pie Chart 1 below for International Studies implemented TQM). 


\section{International Studies in TQM}

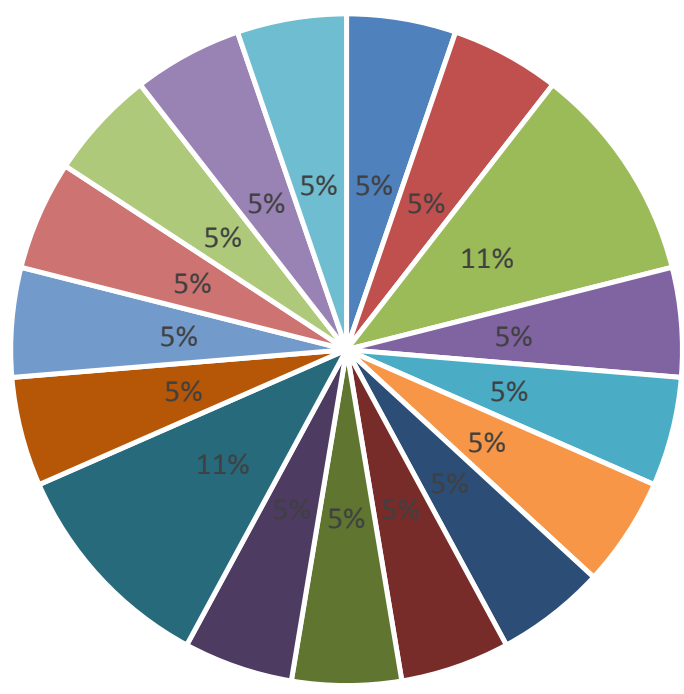

- Multi sectors in $\mathrm{M} / \mathrm{C}$

- Manffacturing in Malaysia

- Health in Canada

- Manffacturing in Libya

- IT in India

- Petrochemical in Middle East
- Manffacturing in Thailand

- Service in Spain

- Manffacturing in Kenya

- Food in Greek

- Manffacturing \& Public in Qatar

- Service in Pakistan

Chart 1. International Studies implemented TQM

Fawziah and Balghonaim (2010) attempted to identify the barriers to the implementation of TQM in public hospitals in Saudi by focusing on key factors such as leadership, commitment, management, human resource, the influence of organisational culture, and to find out their effect on internal customer satisfaction. The study provided a conceptual model as a recommendation while hoping to offer awareness to the problems facing the hospitals.

Bubshit and Al-Anazi, (1999) in their study, identified the critical quality factors amongst Saudi Arabian ISO certified organisations. They began by interpreting the consensus amongst ISO certified organisations regarding the level of perceived importance of each of the five factors. They concluded that the five-factor model is a reliable and valid instrument for measuring the perceived importance of the quality factors to the success of TQM in the respondent's organisation. However, the factors have positive and significant effects on TQM implementation in these organisations. Management commitment and management involvement will be a crucial factor for the successful implementation of TQM, and their total participation is necessary to lead and facilitate the implementation. Communication will be the second most critical success factor. Training and Education will be the third most important success factor. Therefore, those companies which have spent considerable time, effort and investment on the development of employees and teamwork, trained employees would contribute to the success of the business.

In terms of TQM implementation and leadership relationship, there have been some pieces of evidence which suggest that TQM can be successfully improved in the Saudi higher education sector by adopting the best style of leadership and new management system, which will enhance the universities ranking and quality of graduates (Aldaweesh et al., 2012). Moreover, a study by Alzhrani et al. (2016) indicated that Saudi universities have recently started establishing TQM departments to keep track of the quality of education.

Also, Islam et al. (2016) suggest, TQM and Information System (IS) in Saudi organisations is viewed to be beneficial specifically to obtaining greater customer satisfaction and enhancing the quality of delivered products/ services. However, cost cutting and enhancing IS personnel productivity was not highly perceived as a benefit from using 
TQM with IS. Moreover, customers centric and benchmarking were apparent as strongly emphasising the successful features of TQM implementations.

Alhwairini and Foley (2012) emphasise the importance of establishing a clearer understanding of the success factors that contribute to excellence in the workplace to assist organisations in successfully embedding a quality-focused approach. They found out that the selected TQM pre-requisites and the current state within the organisation are not aligned. More so, the study findings indicated that there is a gap between the NFP'S traditional management style and business practices compared with those of TQM.

Table 1. National and international studies on TQM implementation

\begin{tabular}{|c|c|}
\hline Identifier & Paper details \\
\hline 1 & $\begin{array}{l}\text { Aldaweesh M, Al-Karaghouli W, Gallear D (2013) Total quality management (TQM); } \\
\text { Improvement; Leadership; Universities; Saudi Arabia; Higher education HE. European, } \\
\text { Mediterranean \& Middle Eastern Conference on Information Systems (EMCIS 13), Windsor, } \\
\text { United Kingdom. Brunel University 978-1-908549-11-2 }\end{array}$ \\
\hline 2 & $\begin{array}{l}\text { Rahman A, Attar M (2009) Implementation of TQM in Manufacturing Industries in the } \\
\text { Kingdom of Saudi Arabia. 22nd International Congress on Condition Monitoring and } \\
\text { Diagnostic Engineering Management. Griffith School of Engineering, Griffith University, } \\
\text { Gold Coast Campus, QLD 4222, Australia. }\end{array}$ \\
\hline 3 & $\begin{array}{l}\text { Gallear D, Aldaweesh M, Al-Karaghouli W (2012) The relationship between total quality } \\
\text { management implementation and leadership in Saudi higher education: a review and } \\
\text { conceptual framework. European, Mediterranean \& Middle Eastern Conference on } \\
\text { Information Systems (EMCIS2012). Brunel University 978-1-908549-03-7 }\end{array}$ \\
\hline 4 & $\begin{array}{l}\text { Osama I, Yousef B, and Syed H H, (2016) Total Quality Management for Information } \\
\text { Systems in Saudi Firms. International Journal of Computer Applications }(0975-8887) \\
\text { Volume } 134-\text { No.4. }\end{array}$ \\
\hline 5 & $\begin{array}{l}\text { Khadijah M A, Bashayer A A, Azrilah A, (2016) Total Quality Management in Saudi Higher } \\
\text { Education. International Journal of Computer Applications ( } 0975 \text { - 8887) Volume } 135 \text { - No.4 }\end{array}$ \\
\hline 6 & $\begin{array}{l}\text { Fawziah, Balghonaim (2010) Establishing TQM Barriers in Saudi Government Hospitals. } \\
\text { Brunel Business School - Doctoral Symposium }-4 \text { th \& } 5^{\text {th }} \text {. (Online accessed) } \\
\text { https://www.brunel.ac.uk/_data/assets/file/0007/90736/phdSimp2010FawziahBalghoniam.p } \\
\underline{\text { df }}\end{array}$ \\
\hline 7 & $\begin{array}{l}\text { Abdulaziz B, Fahad U (1999) Empirical Study: Critical Success Factors (CSFs) of TQM } \\
\text { implementation in Saudi Arabian Industries. Thesis }\end{array}$ \\
\hline 8 & $\begin{array}{l}\text { Abdulrahman Alhwairini, Andrea Foley, (2012) "Working towards total quality management } \\
\text { in Saudi Arabia", Education, Business and Society: Contemporary Middle Eastern Issues, } \\
\text { Vol. } 5 \text { Issue: 3, pp.187-199, https://doi.org/10.1108/17537981211265570 }\end{array}$ \\
\hline 9 & $\begin{array}{l}\text { Ajinah H M (2009) The Islamic TQM model: an empirical study for the implementation of } \\
\text { total quality management in the Saudi Arabian process manufacturing sector. Thesis. } \\
\text { University of Portsmouth }\end{array}$ \\
\hline 10 & $\begin{array}{l}\text { Faihan M S A (2014) Impact on quality culture of total quality management practices factors. } \\
\text { International Journal of Business \& Economic Development, Volume 2, Number 3, pp. } \\
\text { 35-48(14) }\end{array}$ \\
\hline 11 & $\begin{array}{l}\text { Ahmad I. Al-Shafei, Khalid Bin Abdulrahman, Khalid I. Al-Qumaizi \& Abdelmoniem S. } \\
\text { El-Mardi (2015) Developing a generic model for total quality management in higher } \\
\text { education in Saudi Arabia, Medical Teacher, 37:sup1, S1-S4, DOI: } \\
\text { 10.3109/0142159X.2015.1006607 }\end{array}$ \\
\hline
\end{tabular}


12 Khalid I. Alshitri (2014) An Instrument for Measuring Perception Levels on TQM Practices among R\&D Centre Employees in Saudi Arabia. http://www.ibimapublishing.com/journals/CIBIMA/cibima.html Vol. 2014 (2014), Article ID 473436, 12 pages DOI: $10.5171 / 2014.473436$. IBIMA

\begin{tabular}{|c|c|}
\hline 13 & $\begin{array}{l}\text { Ramadan I. Najeh \& Chakib Kara-Zaitri (2007) A Comparative Study of Critical Quality } \\
\text { Factors in Malaysia, Palestine, Saudi Arabia, Kuwait and Libya, Total Quality Management } \\
\text { \& Business Excellence, 18:1-2, 189-200, DOI: 10.1080/14783360601053400. }\end{array}$ \\
\hline 14 & $\begin{array}{l}\text { Mazen A A (2004) TQM And the Construction Industry (Saudi Arabia -A Case Study). } \\
\text { Thesis }\end{array}$ \\
\hline 15 & $\begin{array}{l}\text { Albayoudh K A.F(2003) Assessment of total quality management in the Saudi construction } \\
\text { industry organisations. Thesis }\end{array}$ \\
\hline 16 & $\begin{array}{l}\text { Jaber M A (2012) The Implementation of Total Quality Management in Education } \\
\text { Directorates in Saudi Arabia Contrasting Provincial Case Studies. Thesis }\end{array}$ \\
\hline 17 & $\begin{array}{l}\text { Hiafa M AL-D (2002) The Impact of TQM On A Traditionally Segregated Work } \\
\text { Environment: An Empirical Study of The Healthcare Sector In The Kingdom Of Saudi } \\
\text { Arabia. Thesis. }\end{array}$ \\
\hline 18 & $\begin{array}{l}\text { Nasseef M A (2009) A Study of The Critical Success Factors For Sustainable TQM: A } \\
\text { Proposed Assessment Model For Maturity And Excellence. Thesis }\end{array}$ \\
\hline 19 & $\begin{array}{l}\text { ASMA A H (2016) Framework to Assess the Level of Readiness for TQM Implementation } \\
\text { In Girls' Secondary Schools In Saudi Arabia. Thesis }\end{array}$ \\
\hline 20 & $\begin{array}{l}\text { Nasser A K (2000) The Quality Management Systems of ISO } 9000 \text { Registered } \\
\text { Firms in A Range of Manufacturing Sectors in Saudi Arabia. Thesis }\end{array}$ \\
\hline 21 & $\begin{array}{l}\text { Hani A A (1995) Total Quality Management in The Saudi Manufacturing Sector Prospects } \\
\text { and Difficulties. Thesis }\end{array}$ \\
\hline 22 & $\begin{array}{l}\text { Soltan Y (2006) Total Quality Management Framework for Libyan Process and } \\
\text { Manufacturing Industries. Thesis }\end{array}$ \\
\hline 23 & $\begin{array}{l}\text { Lina K (2010) Total Quality Environmental Management (TQEM) Framework Towards } \\
\text { Sustainability (UK Novated D\&B Principal Contractors). Thesis }\end{array}$ \\
\hline 24 & $\begin{array}{l}\text { Naser Abdulrahman Alsaleh, (2007) "Application of quality tools by the Saudi food } \\
\text { industry", The TQM Magazine, Vol. } 19 \text { Issue: } 2, \quad \text { pp.150-161, } \\
\text { https://doi.org/10.1108/09544780710729999 }\end{array}$ \\
\hline 25 & $\begin{array}{l}\text { Evangelos Psomas, Fotis Vouzas, Dimitrios Kafetzopoulos, (2014) "Quality management } \\
\text { benefits through the "soft" and "hard" aspect of TQM in food companies", The TQM Journal, } \\
\text { Vol. } 26 \text { Issue: 5, pp.431-444, https://doi.org/10.1108/TQM-02-2013-0017 }\end{array}$ \\
\hline 26 & $\begin{array}{l}\text { Hesham M (2010) Quality Management Standards (QMS) Implementation in Egypt: ISO } \\
9000 \text { Perspectives. Global Business and Management Research: An International Journal. } \\
\text { GBMR. Vol. 2, No. 1, pp. 57-68 }\end{array}$ \\
\hline 27 & $\begin{array}{l}\text { Rupa Mahanti, Jiju Antony, (2009) "Six Sigma in the Indian software industry: some } \\
\text { observations and results from a pilot survey", The TQM Journal, Vol. } 21 \text { Issue: 6, } \\
\text { pp.549-564, https://doi.org/10.1108/17542730910995837 }\end{array}$ \\
\hline 28 & $\begin{array}{l}\text { Khalifa N. Al - khalifa, Elaine M. Aspinwall, (2000) "The development of total quality } \\
\text { management in Qatar", The TQM Magazine, Vol. } 12 \text { Issue: 3, pp.194-204, } \\
\text { https://doi.org/10.1108/09544780010320250 }\end{array}$ \\
\hline
\end{tabular}


29 Muhammad Usman Awan, Abdul Raouf, Niaz Ahmad, Leigh Sparks, (2009) "Total quality management in developing countries: A case of pharmaceutical wholesale distribution in Pakistan", International Journal of Pharmaceutical and Healthcare Marketing, Vol. 3 Issue: 4, pp.363-380, https://doi.org/10.1108/17506120911006056

\begin{tabular}{ll}
\hline 30 & Evangelos L. Psomas, Christos V. Fotopoulos, (2010) "Total quality management practices \\
and results in food companies", International Journal of Productivity and Performance \\
Management, Vol. 59 Issue: 7, pp.668-687, https://doi.org/10.1108/17410401011075657 \\
\hline 31 & Aziz B M A (2013) Application of Total Quality Management in Public Administration of \\
& Education in Taif: possibilities and constraints from the viewpoint of its staff. Dissertation \\
& (Arabic) \\
& Hashem A M S, Alkawath A A A and Othman A A (2015) Impact of applying TQM on \\
& Decreasing Monitoring Procedures in Vehicles Maintenance Centres. \\
& http://journals.sustech.edu/ Total Quality Management Journal 2015, vol. 16 No. (1) ISSN \\
& 1605- 427x e-ISSN. (Arabic) \\
\hline 32 & Jafar M I, Ahmed O I, and Abdulrahman A (2012) Applying Total Quality Management on \\
& Higher Education Services for Continuing Improvement Guaranteeing Input Quality and \\
& Obtaining Accreditation: A Case Study of Taif University Alkhurma Branch. Available \\
& online at www.amarabac.com (Arabic) \\
\hline 34 & M.S. Abd-Elwahed1* \& M.A. El-Baz2 (2018) Impact Of Implementation Of Total Quality \\
& Management: An Assessment Of The Saudi Industry. South African Journal of Industrial \\
Engineering May 2018 Vol 29(1), pp 97-107 (Arabic) \\
\hline Nami A S (2015) Employees' Attitudes in Food Industries Companies in the Kingdom of \\
Saudi Arabia Toward Constraints of the Application of Quality Management Systems. \\
Available online at https://journals.ju.edu.jo/DirasatAdm/article/view/8926 (Arabic) \\
\hline Rabeh M (2014) Requirements for the implementation of TQM comprehensive within \\
sustainability leaders: a case of Albarak bank in Algeria. Thesis (Arabic \\
\hline 35
\end{tabular}

Alotaibi (2014) study identified factors or characteristics of the quality culture of the Saudi construction industry and presented factors affecting TQM practices implementation. The article highlighted that, working with employees, ensuring top management commitment, and having a customer focus, though all the TQM factors were found to be significantly related to quality culture. It also established the importance of quality culture given that TQM factors explain more than two-thirds of the total variance, the impact on competitiveness on TQM factors did explain more than a third of the total. Meanwhile, Al-Shafei et al. (2015) attempted to develop a generic model for quality management in Teaching and Learning (QMTL) in higher education in Saudi Arabia. The study suggested that the model would be selected to provide the quality of education in line with the institutions' strategic aim and objectives. Implementing the generic holistic model for quality management in teaching and learning (QMTL) ensures the adoption of the management principles of the model mentioned-above and emphasising quality management in teaching and learning. This includes the following actions and measures: 
- Transformation of the learners; engagement of students, academics, and administrative staff (leaders) in the teaching and learning;

- Interactive teaching and learning;

- Academic professionalism that emphasises openness, dialogue and transparency and thus improving the staff-student interface;

- Enhancing the learning experience of students by increasing their ability to discern the relevant aspects of variation. This is accomplished by the synergistic involvement of academics in both the teaching and research teams.

- $\quad$ Ensuring the responsive and service-oriented nature of the universities and higher education institutes.

- And finally, building new relationships and partnerships both internally and externally with the community, industry, government, and other institutions locally and internationally.

Alshitri (2014) attempted to develop and validate an instrument to measure perception on TQM practices among Research and Development (R\&D) centre employees in Saudi Arabia. In this study, the researcher found that the TQM framework, as modelled, is a valid and reliable instrument in measuring TQM practices and predicting job satisfaction, organisational commitment, and intentions to stay among R\&D centre employees. Also, it shows that TQM practices are highly correlated with each other.

A comparative study of critical quality factors conducted by Najeh and Zaitri (2007) in five countries, i.e. Malaysia, Palestine, Saudi Arabia, Kuwait and Libya. They argued that the five case studies indicate reasons why a given set of quality factors is preferred than another. In their study, they compared and contrasted the quality visions and practice while examining the comparative adaptability and benchmarking of quality factors towards successful TQM implementation in five countries.

Al-Sinan (2004) research examined the impact of TQM in the construction industry. The researcher identified and analysed the size of TQM awareness in the Saudi construction industry; the difficulties of introducing TQM in the Saudi construction industry; the effectiveness of TQM as a solution for Saudi construction industry problems; the major problems of the Saudi construction industry. It was concluded from the findings that, practical TQM implementation experience in a small construction firm supplemented the findings of other sources, namely the personal interviews and the questionnaire. Also, the findings showed that contractors in the construction industry had developed well-defined routines for logistics and scheduling.

Albayoudh (2003) undertook a comparative study for the TQM models in the construction industry in Saudi. The researcher suggested that there seems to be some evidence from the assessment of TQM that Baldriage National Quality Award (MIBNQA) is more suitable for implementation within the construction industry.

Alruwaili (2012) investigated the current administrative situations in Saudi Arabia's provincial directorates to explore the conditions of TQM implementation in two Saudi Education Directorates. The conclusion was that the directorates already have TQM creativities despite the governmental pressure. Also, the study also revealed profound differences in the two institutional cultures under focus and the ways, managers felt that TQM was impacting on their professional practice and environment (See Pie Chart $2 \& 3$ below for Private and Public organisations implemented TQM). 


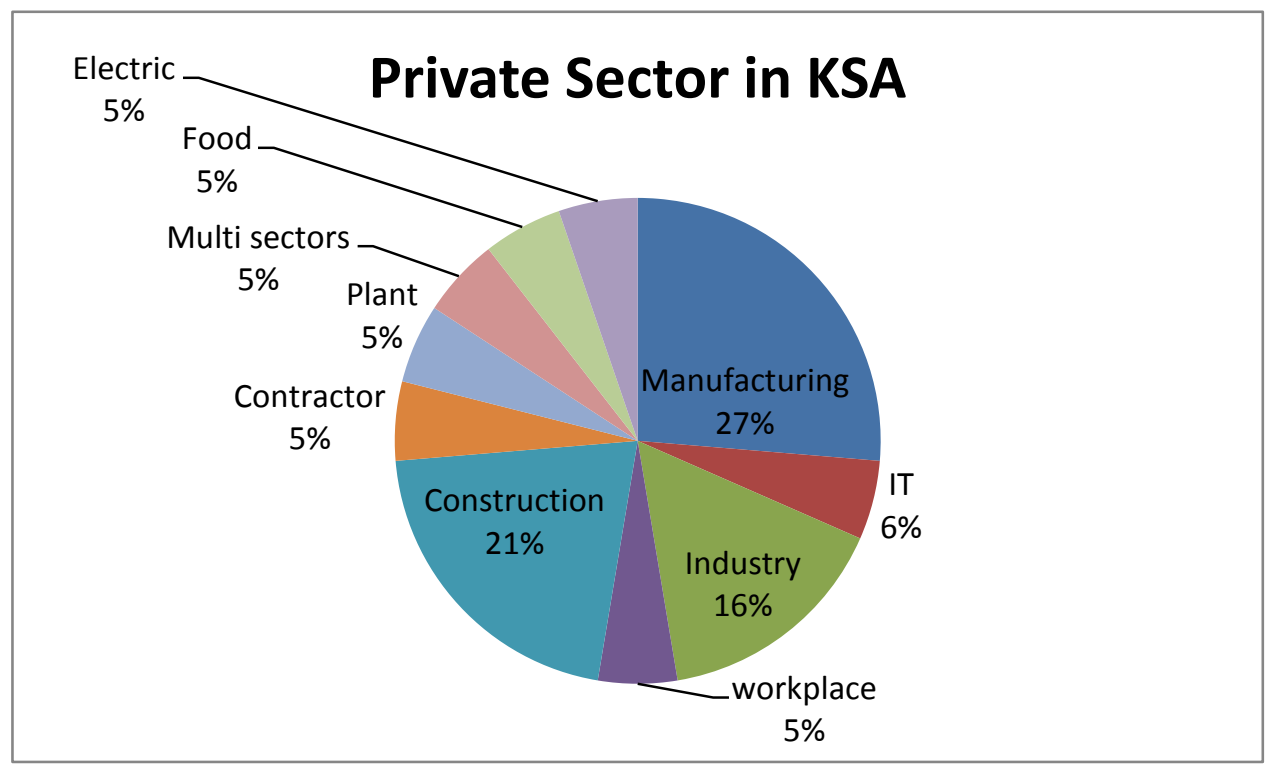

Chart 2. Private Organisations Implemented TQM

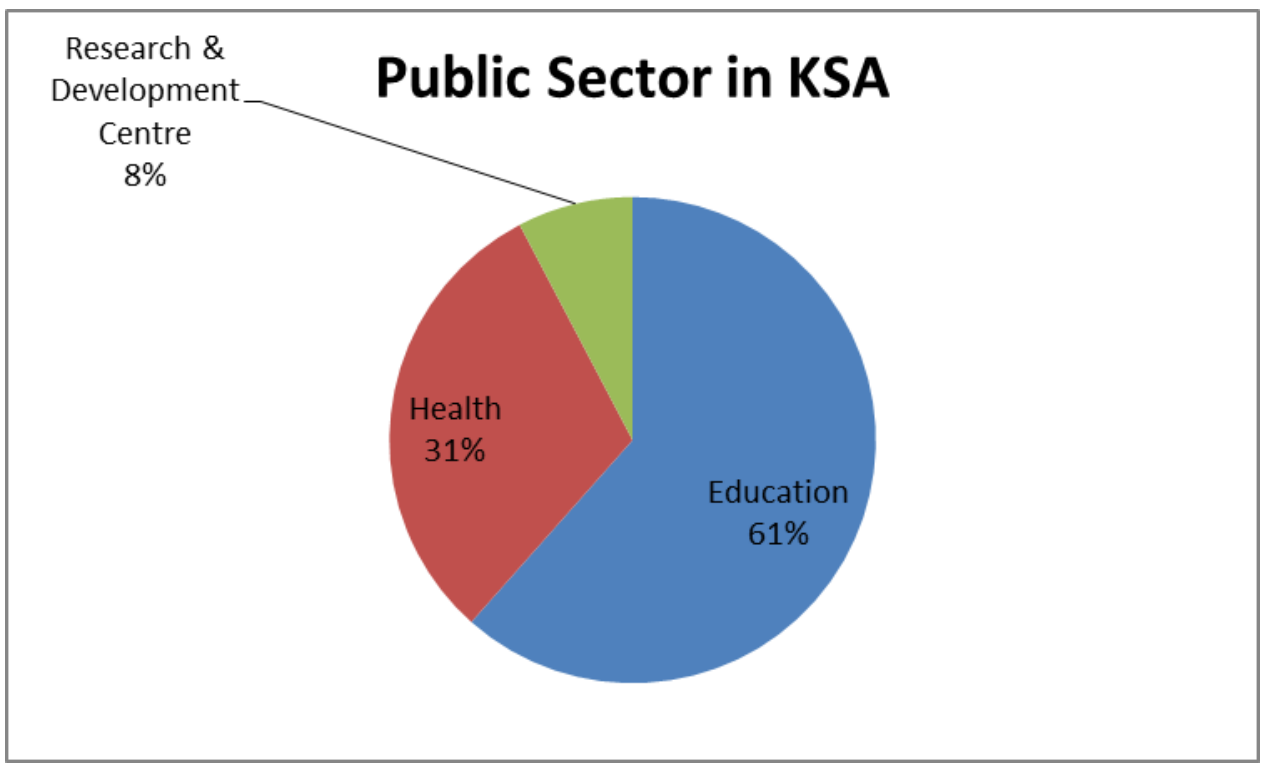

Chart 3. Public Organisations Implemented TQM

Al-Dakheel (2002) empirical study in the health sector in the Kingdom of Saudi Arabia (KSA) was to understand and exam TQM implementation within the health context, and to develop a model for TQM implementation in a segregated environment in the KSA. In this study, it was concluded that there are a weak appreciation, awareness and understanding of TQM in managing healthcare organisations by the respondents in the KSA. It clearly shows that many employees in organisations do not understand TQM. The degree of emphasis for each quality activity varied and thus the need for further impactful research to investigate the importance of each quality activity to a TQM implementation process, as there are varying degrees of emphasis across the board. One could argue that a majority of the KSA cases have not succeeded in total commitment towards a total quality culture.

From table 1 above, we can see there is still a need to study the current situation of TQM implementation and its validation within the manufacturing sector in Saudi Arabia.

In contrast, limited papers were found in TQM implementation in the manufacturing sector in Saudi Arabia (see table 2 below). Rahman and Attar (2009) conducted a TQM implementation survey in the Manufacturing sector in 
Saudi Arabia. They found that many companies in the Western region of the KSA have only applied ISO 9000 QMS, which lead to a low-level awareness of TQM implementation and its benefits. They emphasised that the survey pinpointed some major difficulties such as an increase of paperwork; difficulties in controlling too many suppliers/subcontractors, and understanding different terminologies used in the standards and the need for a full-time quality manager.

Table 2. TQM implementation in the manufacturing sector in Saudi Arabia

\begin{tabular}{|c|c|c|c|c|c|c|c|c|c|c|c|}
\hline $\begin{array}{l}\text { Author's } \\
\text { Names }\end{array}$ & $\begin{array}{l}\text { Title } \\
\text { /Date }\end{array}$ & Regions & $\begin{array}{l}\text { Research Aim } \\
\text { and } \\
\text { Objectives } \\
\end{array}$ & Key Finding & $\begin{array}{l}\text { Method } \\
\text { \&Scope }\end{array}$ & $\begin{array}{l}\text { Type of } \\
\text { study }\end{array}$ & Sector & Model applied & Limitation & Future study & $\begin{array}{l}\text { Research } \\
\text { Questions }\end{array}$ \\
\hline $\begin{array}{l}\text { 1: Rahman, } \\
\text { Anisur, Attar, } \\
\text { Muhammad }\end{array}$ & $\begin{array}{l}\text { Implementation } \\
\text { of TQM in } \\
\text { Manufacturing } \\
\text { Industries in } \\
\text { the Kingdom of } \\
\text { Saudi Arabia } \\
\text { KSA) } \\
2009\end{array}$ & $\begin{array}{l}\text { Western } \\
\text { region } \\
\text { of the } \\
\text { KSA }\end{array}$ & $\begin{array}{l}\text { The objective } \\
\text { of this study is } \\
\text { to investigate } \\
\text { the current } \\
\text { level of } \\
\text { implementation } \\
\text {, prospects and } \\
\text { barriers in } \\
\text { implementing } \\
\text { TQM in } \\
\text { manufacturing } \\
\text { industries in } \\
\text { the KSA }\end{array}$ & $\begin{array}{l}\text { Many companies in } \\
\text { the western region of } \\
\text { the KSA have a } \\
\text { low-level awareness } \\
\text { of TQM } \\
\text { implementation and its } \\
\text { benefits because of } \\
\text { emphasising on the } \\
\text { one aspect of quality } \\
\text { program ISO } 9000 \\
\text { QMS. } \\
\text { The result of the } \\
\text { survey pointed out } \\
\text { some of the major } \\
\text { difficulties of } \\
\text { implementation of } \\
\text { ISO } 9000 \text { QMS such } \\
\text { as an increase in the } \\
\text { amount of paperwork, } \\
\text { difficulties in } \\
\text { controlling too many } \\
\text { suppliers/subcontracto } \\
\text { rs, and understanding } \\
\text { different terminologies } \\
\text { used in the standards } \\
\text { and need for a } \\
\text { full-time quality } \\
\text { manager. }\end{array}$ & $\begin{array}{l}\text { The survey } \\
\text { questionnaire } \\
\text { was developed } \\
\text { and distributed } \\
\text { to different } \\
\text { manufacturing } \\
\text { companies. }\end{array}$ & Empirical & Manufacturing & $\begin{array}{l}\text { The study } \\
\text { presents a } \\
\text { survey on } \\
\text { current quality } \\
\text { control } \\
\text { practices } \\
\text { to assess the } \\
\text { potentiality of } \\
\text { implementing } \\
\text { TQM } \\
\text { technique and } \\
\text { principles to } \\
\text { improve the } \\
\text { customer } \\
\text { satisfactions } \\
\text { and market } \\
\text { share. }\end{array}$ & $\begin{array}{l}\text { The } \\
\text { research } \\
\text { only covers } \\
100 \\
\text { medium to } \\
\text { large size } \\
\text { manufacturi } \\
\text { ng } \\
\text { companies } \\
\text { in the } \\
\text { western } \\
\text { region of } \\
\text { the KSA }\end{array}$ & $\begin{array}{l}\text { Further } \\
\text { investigation } \\
\text { can be } \\
\text { conducted } \\
\text { throughout the } \\
\text { KSA in the } \\
\text { future. As this } \\
\text { study applied } \\
\text { only MCQ type } \\
\text { questionnaire } \\
\text { for the survey, } \\
\text { so some other } \\
\text { forms of survey } \\
\text { tools such as } \\
\text { personal } \\
\text { interview; a } \\
\text { descriptive } \\
\text { questionnaire } \\
\text { can also be } \\
\text { used to come } \\
\text { into a more } \\
\text { accurate } \\
\text { conclusion }\end{array}$ & \\
\hline $\begin{array}{l}\text { 2: Ajinah, } \\
\text { Hisham Maher }\end{array}$ & $\begin{array}{l}\text { The Islamic } \\
\text { TQM model: } \\
\text { an empirical } \\
\text { study for the } \\
\text { implementation } \\
\text { of total quality } \\
\text { management in } \\
\text { the Saudi } \\
\text { Arabian } \\
\text { process } \\
\text { manufacturing } \\
\text { sector } \\
2009\end{array}$ & $\begin{array}{l}\text { Differen } \\
\mathrm{t} \text { cities } \\
\text { in KSA }\end{array}$ & $\begin{array}{l}\text { This research } \\
\text { aims to } \\
\text { examine what } \\
\text { barriers to fully } \\
\text { effective Total } \\
\text { Quality } \\
\text { Management } \\
\text { (TQM) } \\
\text { implementation } \\
\text { currently exist } \\
\text { in the Saudi } \\
\text { process } \\
\text { manufacturing } \\
\text { sector and } \\
\text { explore } \\
\text { whether there } \\
\text { are any } \\
\text { extraordinary } \\
\text { barriers to the } \\
\text { Implementation } \\
\text { which are } \\
\text { specific to this } \\
\text { country }\end{array}$ & $\begin{array}{l}\text { The findings and } \\
\text { recommendations of } \\
\text { these researchers were } \\
\text { more to analyses and } \\
\text { identify the critical } \\
\text { factors to TQM } \\
\text { implementation in the } \\
\text { Muslim } \\
\text { Countries. Although } \\
\text { all these studies were } \\
\text { conducted within the } \\
\text { Muslim contexts, } \\
\text { nevertheless, none of } \\
\text { them has proposed } \\
\text { adequate solutions to } \\
\text { TQM barriers in that } \\
\text { Region and linked } \\
\text { TQM to faith except } \\
\text { for Y. Al-zomany } \\
\text { (2002) who suggested } \\
\text { a model toward } \\
\text { developing and } \\
\text { Islamic quality model. }\end{array}$ & $\begin{array}{l}\text { Case study, } \\
\text { questionnaire } \\
\text { survey }\end{array}$ & Empirical & Manufacturing & $\begin{array}{l}\text { a new } \\
\text { framework } \\
\text { ITQM model } \\
\text { that could } \\
\text { enhance and } \\
\text { improve } \\
\text { the } \\
\text { implementation } \\
\text { of total quality } \\
\text { management in } \\
\text { this sector. } \\
\text { The model } \\
\text { applied to test } \\
\text { the validity by } \\
\text { providing a few } \\
\text { versions of the } \\
\text { model }\end{array}$ & $\begin{array}{l}\text { The study } \\
\text { focusses on } \\
\text { only three } \\
\text { large } \\
\text { manufacturi } \\
\mathrm{ng} \\
\text { organisation } \\
\mathrm{s} \text { in Saudi } \\
\text { Arabia. }\end{array}$ & $\begin{array}{l}\text { Further work } \\
\text { will be required } \\
\text { to apply the } \\
\text { iTQM model } \\
\text { and verify the } \\
\text { extent of its } \\
\text { reliability and } \\
\text { effectiveness in } \\
\text { improving } \\
\text { quality } \\
\text { outcomes for } \\
\text { organisations }\end{array}$ & $\begin{array}{l}\text { 1: What are the } \\
\text { barriers faced by } \\
\text { Saudi Arabia } \\
\text { process } \\
\text { industries? } \\
\text { 2: "at are the } \\
\text { barriers to TQM } \\
\text { implementation } \\
\text { worldwide? } \\
\text { 3: What are } \\
\text { specific barriers to } \\
\text { TQM } \\
\text { implementation in } \\
\text { the } \\
\text { Muslim countries? } \\
\text { 4: Potential } \\
\text { solutions to these } \\
\text { barriers in the } \\
\text { literature of } \\
\text { TQM? } \\
\text { 5: Potential } \\
\text { solutions to these } \\
\text { barriers in Islam? }\end{array}$ \\
\hline $\begin{array}{l}\text { 3: NASSER } \\
\text { AKEIL } \\
\text { KADASAH }\end{array}$ & $\begin{array}{l}\text { The Quality } \\
\text { Management } \\
\text { Systems Of Iso } \\
9000\end{array}$ & $\begin{array}{l}\text { The } \\
\text { study } \\
\text { covers } \\
\text { the }\end{array}$ & $\begin{array}{l}\text { The objective } \\
\text { of this study is } \\
\text { to investigate } \\
\text { the quality }\end{array}$ & $\begin{array}{l}\text { Most of the employees } \\
\text { in quality-related } \\
\text { positions were } \\
\text { expatriates, while the }\end{array}$ & $\begin{array}{l}140 \\
\text { questionnaires } \\
\text { were } \\
\text { distributed to }\end{array}$ & Empirical & Manufacturing & Of ISO 9000 & $\begin{array}{l}\text { The study } \\
\text { only } \\
\text { applied in } \\
\text { the }\end{array}$ & $\begin{array}{l}\text { Further } \\
\text { investigation } \\
\text { can be carried } \\
\text { out to cover }\end{array}$ & $\begin{array}{l}\text { 1: what are the } \\
\text { characteristics of } \\
\text { the ISO } 9000 \\
\text { registered firms in }\end{array}$ \\
\hline
\end{tabular}




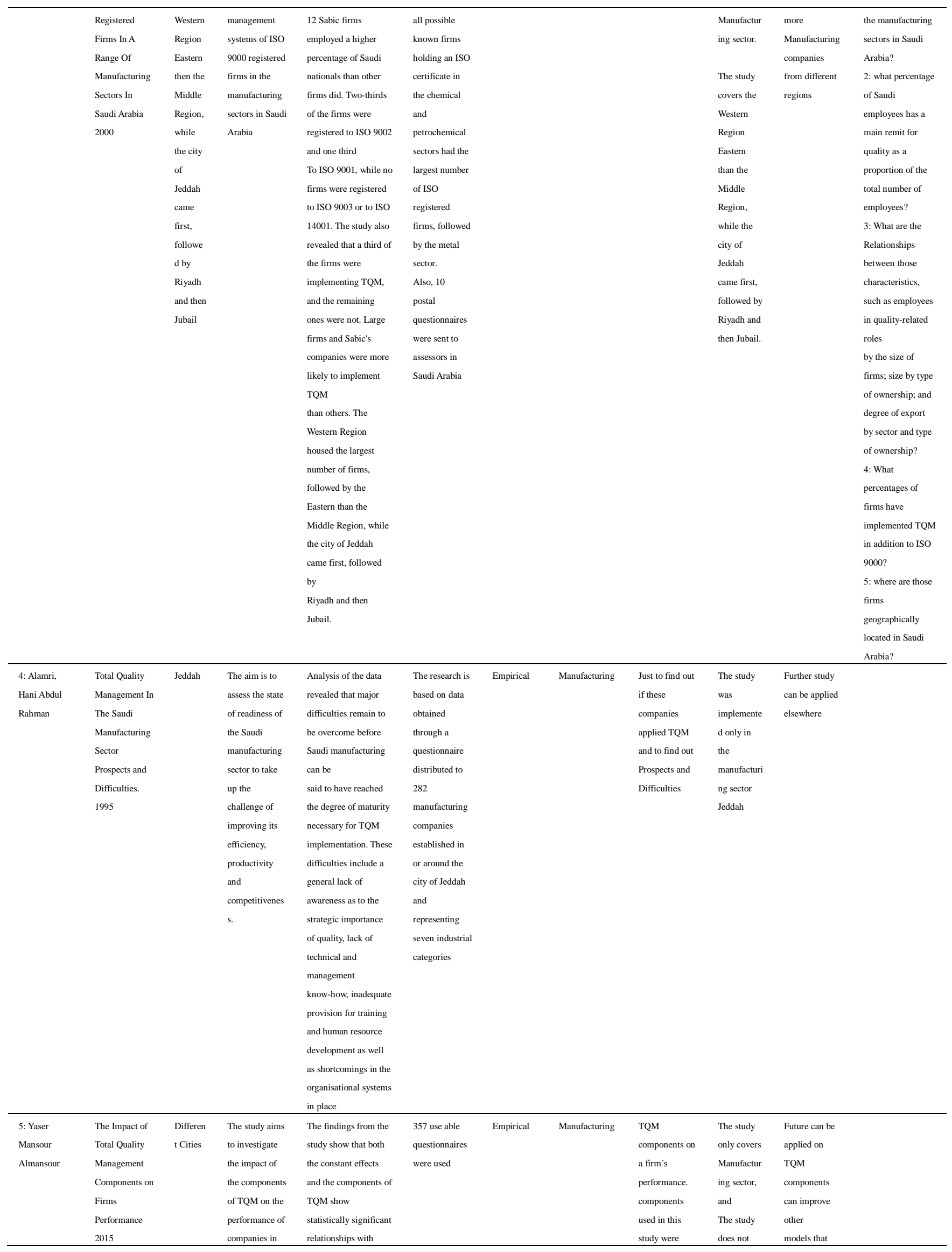




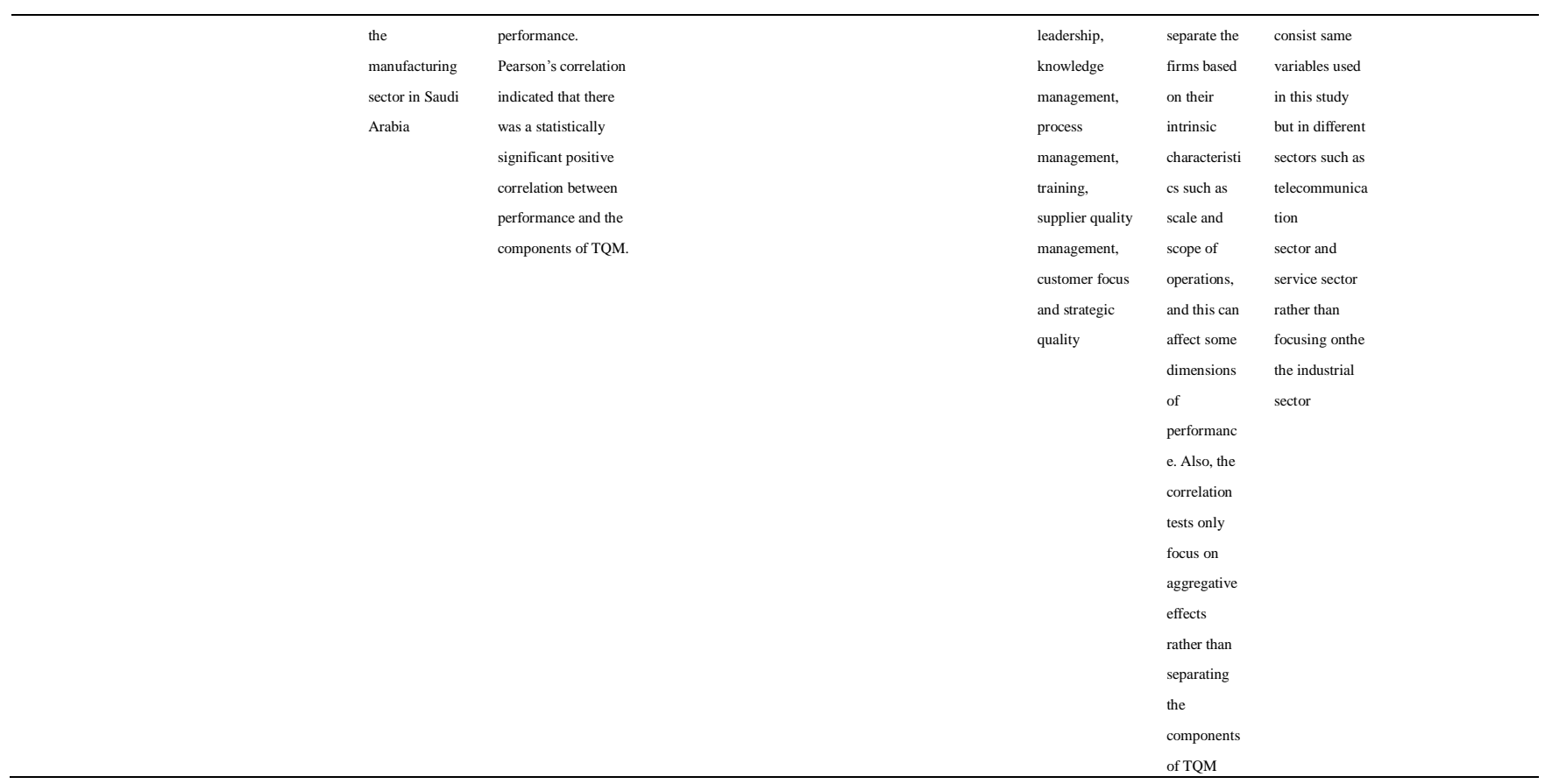

Ajinah (2009) examined barriers to effective TQM implementation that were stifling the Saudi process manufacturing sector to explore whether there were any extraordinary barriers to the Implementation which were country specific to Saudi Arabia. The study analysed and identified the critical factors for TQM implementation in Muslim countries. It found that none of them had proposed adequate solutions to TQM barriers in that region and linked TQM to faith. However, Al-zomany's (2002) work suggested a model for developing an Islamic quality management model.

Nasser (2000) studied the different aspects of quality management systems in ISO 9000 registered firms such as the characteristics of firms; an investigation into their quality systems, which includes some ISO clauses and other elements; and a comprehensive study of the implementation of ISO 9000 in the manufacturing sectors in Saudi Arabia. 140 questionnaires were distributed to all possible known firms holding an ISO. The chemical and petrochemical sectors had the largest number of ISO registered firms, followed by the metal sector, and ISO registration was adopted by all sizes of firms. The Western Region housed the largest number of firms, followed by the Eastern than the Middle Region, while the city of Jeddah came first, and followed by Riyadh and then Jubail.

The study's findings revealed that ISO 9000 registered firms performed well in terms of the quality system elements, and their compliance with ISO clauses. However, many ISO firms tended not to implement advanced and other techniques such as Quality Function Deployment (QFD); benchmarking; cross-functional teams; a vendor rating system; failure mode and effect analysis; and quality circles. The commitment of top managers to ISO was significantly higher than their commitment to quality in general. Companies were generally convinced that ISO benefits were worth the costs. By using factor analysis, the 20 benefits of ISO were reduced to 5 factors: internal benefits; marketing benefits; efficiency benefits; inspection benefits; and quality benefits. Moreover, many respondents and assessors felt the need for the amendment of ISO sections. The Saudi government was found not to play an active role in ISO implementation.

Another study was undertaken by Hani (1995) on TQM within the manufacturing (private) sector in Saudi Arabia. The study revealed that private sector is expected to play a key role through the development of a sound manufacturing base, capable of satisfying local demand and, in the long run, of gaining access to export markets. However, the success of this policy will be underpinned by the capability of the sector to provide high slandered products which meet the requirements of local clients and, the present-day market.

In contradiction to the above, this research attempts to observe the degree of TQM awareness in the manufacturing sector in KSA, the expectations and difficulties facing its implementation. To obtain data, questionnaires were distributed to 282 manufacturing companies in and around the city of Jeddah in different types of businesses. The findings revealed that difficulties remain to be overcome before Saudi manufacturing industry will edge towards a 
better degree of development necessary for TQM implementation. These difficulties include a general lack of awareness to the strategic importance of quality, lack of technical and management know-how, inadequate provision for training and human resource development as well as existential shortcomings in the organisational systems in place. The police indication highlighted the need for long-term solutions to be provided through the intense efforts of both the government and the companies and for greater collaboration between them.

\section{Conclusions}

Even though various studies have been conducted nationally and internationally to investigate Total Quality Management (TQM) implementation and its validation in different sectors, TQM is undoubtedly one of the cornerstones in the manufacturing industry change strategy. This change also involves the Saudization of the marketplace (Fekeeh, 2009; Tayeh and Mustafa, 2011). However, there is a paucity of research investigating the implications of effective implementation of TQM in the manufacturing sector of the Kingdom of Saudi Arabia (KSA).

It is evident from the systematic review that some studies have attempted to identify which TQM model been applied, what barriers, awareness, and difficulties have been faced during the implementation and validation of TQM. They discovered that ISO 9000 was the most applied model within the sector. However, many ISO 9000 companies tended not to implement advanced techniques such as QFD benchmarking; cross-functional teams; a vendor rating system; failure mode and effect analysis; and quality circles.

Furthermore, the findings indicate that the manufacturing sector is facing huge challenges in the adoption and implementation of TQM. The primary challenges include the divergence in views on the strategic importance of quality, the disparity in the professional and technical know-how, weaknesses in the training and development systems, and the limitations that plague the institutional frameworks.

\subsection{Originality/Value}

This systematic review contributes to understanding what has been done in the field of TQM model implementation and its development and validation in the manufacturing sector in Saudi Arabia in recent years. Also, it will uncover interesting study gaps for future research. Therefore, this study is significant on the basis that will customise a TQM model that explains the interaction between the variables that influence quality management within the sector in some ways.

- It will contextualise the TQM which applies within the manufacturing sector in KSA in Jeddah and provide companies with a specific set of factors which enhance the achievement of quality objectives.

- It will launch a foundation for improvement in TQM, by increasing the ability of the companies to achieve efficiency and effectiveness.

- It will increase the awareness of the role of TQM in the manufacturing sector in the country, by highlighting how it influences organisational performance, and how it has developed over time.

- The customise model will provide a TQM framework that involves the most prominent dimensions of quality in the industry, to ensure that the strategies that are made by the companies based on the model are relevant and viable for the industry.

- $\quad$ Finally, it will offer policy and strategy makers with a customised model that outlines the role of each essential of TQM within the companies, from the perception of a multiplicity of stakeholders, to gain a comprehensive understanding of the choices within the various companies involved in the industry.

To conclude, this study is an extension of past research and will target a unique sample, while focusing on emergent theories and techniques, and accommodating the ever-changing environment in the Saudi manufacturing sector.

\section{Limitations}

There are a plethora of constraints as per the effective implementation of TQM in KSA and the Middle East in general due to a lag in the adoption of TQM; the industry faces challenges in optimising the outcomes, or lack of resources to invest in the TQM process (Aisha, 2017). One might argue that an extensive systematic review of the efficient TQM implementation in Saudi Arabia is inevitably essential.

\section{Acknowledgements}

To my supervision team Prof Dawood, Nashwan and Dr Crosbie, Tracey, for their valuable help and direction throughout the preparation of this paper. Their invaluable advice, supervision and inspiration were instrumental in me achieving completion of, and then further enhancing this work. 


\section{References}

Abdulaziz B, Fahad U. (1999). Empirical Study: Critical Success Factors (CSFs) of TQM implementation in Saudi Arabian Industries.

Abdulrahman Alhwairini, Andrea Foley. (2012). Working towards total quality management in Saudi Arabia. Education, Business and Society: Contemporary Middle Eastern Issues, 5(3), 187-199, https://doi.org/10.1108/17537981211265570

Ahmad I. Al-shafei, Khalid Bin Abdulrahman, Khalid I. Al-Qumaizi \& Abdelmoniem S. El-Mardi. (2015). Developing a generic model for total quality management in higher education in Saudi Arabia. Medical Teacher, 37(1), S1-S4. https://doi.org/10.3109/0142159X.2015.1006607

Ajinah H M. (2009). The Islamic TQM model: an empirical study for the implementation of total quality management in the Saudi Arabian process manufacturing sector. Thesis. University of Portsmouth.

Albayoudh K A.F. (2003). Assessment of total quality management in the Saudi construction industry organisations.

Aldaweesh M, Al-Karaghouli W, Gallear D. (2013). Total quality management (TQM); Improvement; Leadership; Universities; Saudi Arabia; Higher education HE. European, Mediterranean \& Middle Eastern Conference on Information Systems (EMCIS 13), Windsor, United Kingdom. Brunel University 978-1-908549-11-2.

ASMA A H. (2016). Framework to Assess the Level of Readiness for TQM Implementation In Girls' Secondary Schools In Saudi Arabia.

Aziz B M A. (2013). Application of Total Quality Management in Public Administration of Education in Taif: possibilities and constraints from the viewpoint of its staff. Dissertation (Arabic) Directorates in Saudi Arabia Contrasting Provincial Case Studies.

Evangelos L. Psomas, Christos V. Fotopoulos. (2010). Total quality management practices and results in food companies. International Journal of Productivity and Performance Management, 59(7), 668-687, https://doi.org/10.1108/17410401011075657

Evangelos Psomas, Fotis Vouzas, Dimitrios Kafetzopoulos. (2014). Quality management benefits through the "soft" and "hard" aspect of TQM in food companies. The TQM Journal, 26(5), 431-444, https://doi.org/10.1108/TQM-02-2013-0017

Faihan M S A. (2014). Impact on quality culture of total quality management practices factors. International Journal of Business \& Economic Development, 2(3), 35-48(14).

Fawziah, Balghonaim. (2010). Establishing TQM Barriers in Saudi Government Hospitals. Brunel Business School Doctoral Symposium $\quad-\quad 4$ th $\quad \& \quad$ th. $\quad$ (online https://www.brunel.ac.uk/_data/assets/file/0007/90736/phdSimp2010FawziahBalghoniam.pdf

Gallear D, Aldaweesh M, Al-Karaghouli W. (2012). The relationship between total quality management implementation and leadership in the Saudi higher education: a review and conceptual framework. European, Mediterranean \& Middle Eastern Conference on Information Systems (EMCIS2012). Brunel University 978-1-908549-03-7.

Hani A A. (1995). Total Quality Management in The Saudi Manufacturing Sector Prospects and Difficulties.

Hashem A M S, Alkawath A A \& Othman A A. (2015). Impact of applying TQM on Decreasing Monitoring Procedures in Vehicles Maintenance Centres. Total Quality Management Journal, 16(1).

Hesham M. (2010). Quality Management Standards (QMS) Implementation in Egypt: ISO 9000 Perspectives. Global Business and Management Research: An International Journal. GBMR, 2(1), 57-68

Hiafa M AL-D. (2002). The Impact of TQM On A Traditionally Segregated Work Environment: An Empirical Study of The Healthcare Sector in The Kingdom of Saudi Arabia.

J Likita, A, Zainun, N Y, Abdul R I, S M Abdul A A, R Alias A, Q Abdul R M, Ghazali, F. (2018). An Overview of Total Quality Management (TQM) practice in Construction Sector. IOP Conference Series: Earth and Environmental Science. https://doi.org/10.1088/1755-1315/140/1/012115

Jaber M A. (2012). The Implementation of Total Quality Management in Education. 
Jafar M I, Ahmed O I, \& Abdulrahman A. (2012). Applying Total Quality Management on Higher Education Services for Continuing Improvement Guaranteeing Input Quality and Obtaining Accreditation: A Case Study of Taif University Alkhurma Branch. [Online] Available: www.amarabac.com (Arabic).

Khadijah M A, Bashayer A A, Azrilah A. (2016). Total Quality Management in Saudi Higher Education. International Journal of Computer Applications (0975 - 8887), 135(4).

Khalid I. Alshitri. (2014). An Instrument for Measuring Perception Levels on TQM Practices among R\&D Centre Employees in Saudi Arabia. https://doi.org/10.5171/2014.473436

Khalifa N. Al - khalifa, Elaine M. Aspinwall. (2000). The development of total quality management in Qatar. The TQM Magazine, 12(3), 194-204. https://doi.org/10.1108/09544780010320250

Lina K. (2010). Total Quality Environmental Management (TQEM) Framework Towards Sustainability (UK Novated D\&B Principal Contractors).

M.S. Abd-Elwahed1 \& M.A. El-Baz. (2018). Impact of Implementation of Total Quality Management: An Assessment of The Saudi Industry. South African Journal of Industrial Engineering May 2018, 29(1), 97-107 (Arabic)

Mazen A A. (2004). TQM and The Construction Industry (Saudi Arabia -A Case Study).

Muhammad Usman Awan, Abdul Raouf, Niaz Ahmad, Leigh Sparks. (2009). Total quality management in developing countries: A case of pharmaceutical wholesale distribution in Pakistan. International Journal of Pharmaceutical and Healthcare Marketing, 3(4), 363-380. https://doi.org/10.1108/17506120911006056

Nami A S. (2015). Employees' Attitudes in Food Industries Companies in the Kingdom of Saudi Arabia Toward Constraints of the Application of Quality Management Systems. [Online] Available: https://journals.ju.edu.jo/DirasatAdm/article/view/8926 (Arabic)

Naser Abdulrahman Alsaleh. (2007). Application of quality tools by the Saudi food industry. The TQM Magazine, 19(2), 150-161. https://doi.org/10.1108/09544780710729999

Nasseef M A. (2009). A Study of The Critical Success Factors for Sustainable TQM: A Proposed Assessment Model for Maturity and Excellence.

Nasser A. K. (2000). The Quality Management Systems of Iso 9000 Registered Firms in A Range of Manufacturing Sectors in Saudi Arabia.

Noman M, Huma H K. (2011). Total Quality Management in Manufacturing Industry of Pakistan: A Case of Cement Industry. International Conference on Trends in Mechanical and Industrial Engineering (ICTMIE'2011) Bangkok.

Osama I, Yousef B, \& Syed H H. (2016). Total Quality Management for Information Systems in Saudi Firms. International Journal of Computer Applications (0975 - 8887), 134(4).

Rabeh M. (2014). Requirements for the implementation of TQM comprehensive within sustainability leaders: a case of Albarak bank in Algeria. Thesis (Arabic)

Rahman A, Attar M. (2009). Implementation of TQM in the Manufacturing Industries in the Kingdom of Saudi Arabia. 22nd International Congress on Condition Monitoring and Diagnostic Engineering Management. Griffith School of Engineering, Griffith University, Gold Coast Campus, QLD 4222, Australia.

Ramadan I. Najeh \& Chakib Kara-Zaitri. (2007). A Comparative Study of Critical Quality Factors in Malaysia, Palestine, Saudi Arabia, Kuwait and Libya. Total Quality Management \& Business Excellence, 18, 1-2, 189-200. https://doi.org/10.1080/14783360601053400

Rupa Mahanti, Jiju Antony. (2009). Six Sigma in the Indian software industry: some observations and results from a pilot survey. The TQM Journal, 21(6), 549-564. https://doi.org/10.1108/17542730910995837

Soltan Y. (2006). Total Quality Management Framework for Libyan Process and Manufacturing Industries.

Talib, F., \& Rahman, Z. (2012). Total quality management practices in manufacturing and service industries: A comparative study. International Journal of Advanced Operations Management, 4(3), 155-176. 